\title{
PENGEMBANGAN MODUL PEMBELAJARAN DENGAN PENDEKATAN DISCOVERY LEARNING PADA MATERI LIMIT FUNGSI ALJABAR KELAS X DI SMA INSAN CENDEKIA SUKOHARJO TAHUN AJARAN 2015/2016
}

\author{
Setyati Puji Wulandari ${ }^{1}$, Budiyono $^{2}$, Isnandar Slamet ${ }^{3}$ \\ ${ }^{1,2,3}$ Prodi Magister Pendidikan Matematika, FKIP Universitas Sebelas Maret Surakarta
}

\begin{abstract}
The aims of this research were to: 1) determine the validity of the results of the development of learning modules with discovery learning approach on the material of limit algebra functions; 2) determine the practicality of the development of learning modules; 3) determine the effectiveness of the development of learning modules; 4) determine whether students achievement in the material of limit algebra functions using learning modules is better than the students who don't use it. The development of the modules was done through the modified Four D, namely define, design, development, and disseminate. Data were analyzed using descriptive analysis. Validity analysis was based on an expert assessment. Practicality analysis was based on implementation of learning module. Effectiveness analysis was based on student response after using the module. Analysis of student achievement was based on t-test hypothesis. The result concluded that: 1) learning modules with discovery learning approach to the material limit algebra functions declared fit for use by experts with the validity score of 3.44 and be in very good criteria; 2) learning modules expressed practical use in learning with the practicality score gained from the sheet of implementation of learning is 0.919 and be in very good criteria; 3) learning modules is effective for use in learning with the scores of effectiveness obtained from the sheet of student's response to the module is 3.03 and be in good criteria; 4) learning achievement of students who use the learning module is better than students who don't use it, but isn't significant.
\end{abstract}

Keywords: learning module, discovery learning, limit algebra functions.

\section{PENDAHULUAN}

Pembelajaran merupakan proses aktif yang dihasilkan melalui keterlibatan aktif individu dalam merefleksikan pengalaman dan tindakan yang dipraktikkan di lingkungan tertentu (Huda, 2014: 38). Adanya proses aktif dan keterlibatan individu dalam proses belajar ini diharapkan siswa mendapatkan pengalaman yang berkesan dan bermakna dalam belajar. Jennifer R. Nichols mengemukakan empat prinsip pembelajaran abad 21, yaitu pembelajaran seharusnya berpusat pada siswa, pendidikan seharusnya dilaksanakan secara kolaborasi, pembelajaran seharusnya memiliki konteks, dan sekolah seharusnya terintegrasi dengan masyarakat (Nichols, 2013). Pendekatan pembelajaran seyogyanya berpusat pada siswa. Siswa tidak sekedar duduk, mendengar, dan menghafal materi, melainkan berupaya untuk mengonstruksi pengetahuan sendiri. Untuk itu sekolah perlu memfasilitasi siswa untuk aktif, menyediakan bahan pelajaran yang dapat mendorong siswa untuk mengonstruksi pengetahuan sendiri dan berpartisipasi dalam lingkungan sosialnya. Pembelajaran matematika diharapkan mampu mengajarkan siswa untuk belajar secara mandiri dalam tim, berpikir kritis dan memecahkan masalah, serta berkomunikasi 
dengan baik. Kemampuan berpikir kritis dan pemecahan masalah pada siswa dapat distimulus dan diasah melalui proses pembelajaran yang bermakna. Proses pembelajaran dikatakan bermakna jika siswa dapat aktif selama proses pembelajaran sedemikian hingga siswa mampu mengonstruksi sendiri pengetahuannya melalui serangkaian kegiatan yang mendorong siswa untuk melakukan penemuan. Pembelajaran ini memberikan kesan pengalaman langsung bagi siswa sehingga siswa merasa percaya diri untuk mempelajari materi secara mandiri dengan bantuan media ajar yang tepat (Chambers, et al.,2013). Peran guru dalam hal ini sebagai fasilitator yang menyediakan pengalaman belajar, sarana belajar yang dapat merangsang siswa berpikir kritis, dan menilai hasil belajar siswa.

Ausubel penggagas meaningful learning menyatakan sebagaimana dikutip Orton (1987), "if I had to reduce all of educational psychology to just one principle, I would say this: The most important single factor influencing learning is what the learner already knows. Ascertain this and teach him accordingly". Faktor paling utama yang mempengaruhi pembelajaran adalah bahwa apa yang pembelajar ketahui, sehingga guru dapat memastikan hal ini dan mengajarinya dengan sesuai. Agar pembelajaran menjadi bermakna, maka pembelajaran didesain untuk mendorong siswa melakukan suatu penemuan. Untuk memenuhi hal tersebut, pembelajaran didesain dan dikolaborasikan dengan pendekatan discovery learning. Pembelajaran dengan discovery learning membawa siswa untuk mengorganisasi sendiri pengetahuannya karena materi ajar tidak disajikan dalam bentuk finalnya. Siswa dituntut untuk melakukan berbagai kegiatan seperti menemukan tujuan pembelajaran, menghimpun informasi, membandingkan, mengkategorikan, menganalisis, mengintegrasikan, mereorganisasikan materi pelajaran serta membuat kesimpulan. Dengan demikian seorang guru dalam discovery learning harus dapat menempatkan siswa pada kesempatan dalam belajar yang lebih mandiri. Bruner mengatakan bahwa proses belajar akan berjalan dengan baik dan kreatif jika guru memberikan kesempatan kepada siswa untuk menemukan suatu konsep, teori, aturan, atau pemahaman melalui contoh-contoh yang dijumpai dalam kehidupannya (Budianingsih, 2005:41). Pembelajaran dengan pendekatan discovery learning, memiliki karakteristik stimulation, problem statement, data collection, data processing, verification, dan generalization (Syah, 2004). Dengan menerapkan pembelajaran dengan pendekatan discovery learning, diharapkan siswa dapat berpartisipasi aktif dalam pembelajaran, berpikir kritis dan kreatif, belajar bagaimana belajar, mencapai kemampuan optimal, membekas dalam pikiran karena siswa terlibat dalam proses menemukan konsep. 
Berdasarkan wawancara yang dilakukan dengan guru matematika SMA di Sukoharjo, proses pembelajaran siswa di kelas belum dapat dikatakan optimal. Hal ini ditunjukkan dengan sebagian siswa tidak memperhatikan penjelasan guru, tidak memiliki inisiatif membaca buku pegangan sebelum pelajaran dimulai dan tidak mengerjakan lembar aktivitas siswa jika tidak mendapat perintah. Siswa juga kurang memiliki keberanian untuk mengemukakan pendapatnya maupun bertanya apabila menemui kesulitan.

Berdasarkan laporan hasil UN SMA tahun 2013/2014 (Balitbang Kemdikbud, 2014), materi limit fungsi merupakan materi yang cukup rendah tingkat penguasaannya, yaitu di Kabupaten Sukoharjo sebesar 44,09\%. Persentase penguasaan ini paling rendah dibandingkan kabupaten lain yaitu Kota Surakarta 54,37\%, Kabupaten Klaten 47,06\%, Kabupaten Karanganyar 46,90\%, tingkat Provinsi Jawa Tengah 51,81\%, dan tingkat nasional 51,88\%. Laporan hasil UN SMA tahun 2014/2015 (Balitbang Kemdikbud, 2015), persentase penguasaan materi limit fungsi di Kabupaten Sukoharjo sebesar $43,60 \%$ dan lebih rendah dibandingkan Kota Surakarta 54,49\%, Kabupaten Klaten $47,71 \%$, serta tingkat nasional $53,41 \%$. Rendahnya penguasaan materi ini mengindikasikan adanya ketidakoptimalan siswa dalam belajar. Ketidakoptimalan tersebut salah satunya karena buku pegangan siswa kurang menarik dan sulit dipelajari mandiri, yang mengakibatkan siswa sangat tergantung oleh penjelasan detail dari guru.

Untuk memfasilitasi siswa dalam melakukan pembelajaran yang mandiri dan bermakna adalah dengan mengoptimalkan proses pembelajaran melalui bahan ajar yang mendorong siswa untuk melakukan penemuan. Modul adalah seperangkat bahan ajar yang disajikan secara sistematis sehingga penggunanya dapat belajar dengan atau tanpa seorang fasilitator (Depdiknas, 2008: 20). Modul adalah bahan belajar yang dirancang secara sistematis berdasarkan kurikulum tertentu dan dikemas dalam bentuk satuan pembelajaran terkecil dan memungkinkan dipelajari secara mandiri dalam satuan waktu tertentu (Purwanto, 2007: 9). Modul memiliki karakteristik petunjuk mandiri, kesatuan isi, berdiri sendiri, adaptif, dan bersahabat (Daryanto, 2013: 9-11). Modul pembelajaran dengan pendekatan discovery learning memiliki karakteristik stimulation, problem statement, data collection, data processing, verification, dan generalization. Pada permulaan, siswa dihadapkan pada masalah yang mengantarkan untuk mempelajari materi tertentu. Siswa dipandu untuk mengidentifikasi masalah yang relevan dengan materi pelajaran. Siswa berdiskusi dalam kelompok untuk mengumpulkan informasi relevan, mengolah dan menafsirkannya. Siswa melakukan pemeriksaan untuk 
membuktikan benar atau tidaknya penyelesaian. Terakhir, siswa menarik kesimpulan yang berlaku untuk masalah yang sama.

\section{METODE PENELITIAN}

Penelitian ini adalah penelitian pengembangan (research and development). Produk yang dikembangkan adalah modul pembelajaran dengan pendekatan discovery learning pada materi limit fungsi aljabar. Model pengembangan menggunakan Four D termodifikasi, dengan tahapan define, design, development, dan disseminate. Tahap define meliputi analisis awal-akhir, analisis pebelajar, analisis tugas dan konsep, dan tujuan instruksional khusus. Tahap design meliputi penyusunan modul dengan RPP nya, serta instrumen penilaian modul yang meliputi instrumen untuk mengukur kevalidan, kepraktisan, dan keefektifan modul. Tahap development meliputi pengembangan hingga pemerolehan fisik modul pembelajaran dengan pendekatan discovery learning melalui penilaian ahli (validator) dan uji coba terbatas. Validator yang terlibat adalah ahli materi dan kurikulum pembelajaran serta ahli media dan menulis. Aspek yang divalidasi ahli materi dan kurikulum pembelajaran mencakup aspek kelayakan isi, komponen penyajian, komponen kebahasaan, dan pendekatan discovery learning. Aspek yang divalidasi ahli media dan menulis mencakup kelayakan kegrafikaan. Setelah proses validasi, dilakukan revisi pada bagian-bagian modul yang memerlukan perbaikan sehingga menghasilkan draf II modul. Selanjutnya draf II modul diberikan kepada validator dan dilakukan proses validasi kedua dan seterusnya hingga validator menyatakan tidak perlu ada revisi kembali. Uji coba lapangan dilakukan di SMA Assalam dengan tujuan memperoleh data mengenai kepraktisan dan keefektifan modul. Tahap disseminate meliputi pencetakan dan pendistribusian modul untuk siap digunakan dalam pembelajaran. Pengujian modul dilakukan di SMA Insan Cendekia dengan mengambil dua kelas sebagai kelas eksperimen dan kelas kontrol. Pengujian modul dilakukan dengan tujuan untuk mengetahui apakah prestasi belajar siswa yang menggunakan modul lebih baik daripada siswa yang tidak menggunakan modul. Sebelum dilakukan proses pembelajaran, dilakukan prasyarat yaitu uji normalitas, homogenitas, dan keseimbangan terhadap kelas eksperimen dan kontrol.

\section{HASIL PENELITIAN DAN PEMBAHASAN}

Pengembangan modul pembelajaran dalam penelitian ini mengacu pada model Four D termodifikasi. Tahap define (pendefinisian) menghasilkan submateri apa saja pada materi limit fungsi aljabar yang dapat disampaikan sesuai dengan karakteristik 
discovery learning dan bagaimana bentuk penyajian materinya. Materi tidak disajikan secara utuh, melainkan siswa diajak untuk menemukan materi itu sendiri melalui instruksi-instruksi dalam modul. Hal ini sesuai dengan tujuan discovery learning (Cruickshank, et al., 2009) yaitu agar siswa berpikir tentang kebutuhannya dalam belajar, bagaimana membentuk pengetahuan, dan menggunakan kemampuan berpikir kritis. Penyajian materi dalam modul menggunakan proses penarikan kesimpulan dengan cara induktif, yaitu siswa diberikan contoh-contoh masalah untuk kemudian ditarik kesimpulan secara umum. Proses penarikan kesimpulan secara induktif ini dibenarkan dalam pembelajaran matematika SMA dimana pemahaman konsep sering diawali secara induktif melalui pengamatan pola atau fenomena, pengalaman peristiwa nyata atau intuisi (Salinan Lampiran III Permendikbud No 59 Tahun 2014, 2014: 325). Dari cara kerja matematika tersebut, diharapkan akan terbentuk sikap kritis, kreatif, jujur, dan komunikatif pada peserta didik. Kata-kata yang digunakan dalam modul menggunakan bahasa yang sederhana sehingga diharapkan mudah dimengerti oleh siswa kelas X SMA. Penyajian materi dalam modul menggunakan kalimat-kalimat instruksi yang mengajak atau mendorong siswa untuk melakukan sesuatu agar mencapai tujuan pembelajaran. Menurut Salinan Lampiran III Permendikbud No 59 Tahun 2014 (2014: 364), peran guru dalam hal ini adalah menyatakan permasalahan kemudian membimbing siswa untuk menemukan penyelesaian dari permasalahan itu dengan perintah-perintah atau penggunaan LK. Siswa mengikuti petunjuk yang tersedia dan menemukan sendiri penyelesaiannya. Siswa juga diberikan ruang diskusi dalam menuliskan langkah penyelesaian masalah dalam modul.

Tahap design (desain) meliputi pembuatan modul, RPP dan instrumen penilaian modul. Guru dan praktisi pendidikan hendaknya menyajikan bahan yang dikuasai oleh siswa menggunakan strategi, metode, dan media belajar yang tepat (Salinan Lampiran III Permendikbud No 59 Tahun 2014, 2014: 365). Untuk memfasilitasi proses belajar tersebut dilakukan manipulasi bahan pelajaran sesuai dengan tingkat perkembangan kognitif siswa (Salinan Lampiran III Permendikbud No 59 Tahun 2014, 2014: 376). Tahap perkembangan kognitif seseorang pada usia 14-18 tahun adalah tahap ikonik menuju simbolik. Siswa memahami objek melalui visualisasi kemudian mulai memiliki ide abstrak dari kemampuan bahasa dan logika. Modul pembelajaran dengan karakteristik discovery learning ini materi disampaikan melalui grafik, tabel, sekaligus kalimat instruksi yang mendorong siswa dalam berpikir pemecahan masalah. Bagi siswa dengan perkembangan kognitifnya pada tahap simbolik, maka tanpa mengamati grafik ia dapat menyelesaikan masalah langsung melalui instruksi yang diberikan. Namun bagi siswa 
yang perkembangan kognitifnya pada tahap ikonik, maka siswa dibantu memahami permasalahan melalui pengamatan grafik terlebih dahulu kemudian menyelesaikan permasalahan dengan mengikuti instruksi yang diberikan.

Instrumen penilaian modul yang digunakan dalam penelitian ini adalah instrumen untuk mengukur kevalidan, kepraktisan, dan keefektifan modul. Instrumen kevalidan modul diadaptasi dari pedoman penilaian buku teks pelajaran dari Standar Penilaian Buku Teks Pelajaran oleh BSNP serta ditambah aspek pendekatan discovery learning. Instrumen kepraktisan modul mengacu pada pedoman pelaksanaan pembelajaran Permendikbud RI No 103 tahun 2014 tentang pembelajaran pada pendidikan dasar dan pendidikan menengah yang terdiri dari kegiatan apa saja yang dilakukan pada pendahuluan, inti, dan penutup yang disesuaikan dengan modul pembelajaran. Instrumen keefektifan modul ditinjau dari segi kepuasan pengguna dalam hal ini adalah siswa. Kepuasan dinilai dari segi tampilan, materi, dan manfaat pemakaian modul pembelajaran.

Tahap development (pengembangan) meliputi penilaian ahli dan uji coba modul. Dari penilaian ahli, modul yang dikembangkan telah memenuhi lima aspek kelayakan yaitu kelayakan isi, komponen penyajian, kebahasaan, kegrafikaan, dan pendekatan discovery learning. Hasil validasi oleh ketiga validator tersebut terangkum pada Tabel 1.

Tabel 1. Perhitungan Skor Kevalidan Modul

\begin{tabular}{|c|c|c|c|c|c|c|c|}
\hline \multirow{2}{*}{ Validator } & \multicolumn{4}{|c|}{ Skor } & \multirow{2}{*}{$\begin{array}{l}\text { Jumlah } \\
\text { Butir }\end{array}$} & \multirow{2}{*}{$\begin{array}{l}\text { Jumlah } \\
\text { Skor }\end{array}$} & \multirow{2}{*}{$\begin{array}{c}\text { Rerata } \\
\text { Skor }\end{array}$} \\
\hline & 1 & 2 & 3 & 4 & & & \\
\hline $\begin{array}{l}\text { Dr. Sumardyono, M.Pd } \\
\text { (Ahli Materi dan Ahli } \\
\text { Kurikulum-Pembelajaran) }\end{array}$ & 0 & 0 & 28 & 26 & 54 & 188 & 3,48 \\
\hline $\begin{array}{l}\text { Mujapar, M.Pd } \\
\text { (Ahli Materi dan Ahli } \\
\text { Kurikulum-Pembelajaran) }\end{array}$ & 0 & 0 & 28 & 26 & 54 & 188 & 3,48 \\
\hline $\begin{array}{l}\text { Dr. Sumardyono, M.Pd } \\
\text { (Ahli Media dan Ahli Menulis) }\end{array}$ & 0 & 0 & 34 & 20 & 54 & 102 & 3,37 \\
\hline $\begin{array}{l}\text { Marfuah, S.Si, M.T } \\
\text { (Ahli Media dan Ahli Menulis) }\end{array}$ & 0 & 0 & 30 & 24 & 54 & 186 & 3,44 \\
\hline
\end{tabular}

Dari penilaian ketiga ahli (validator), modul disimpulkan berada pada kriteria baik dan layak digunakan tanpa perbaikan, dengan skor kevalidan modul adalah 3,4 dari skala 4.

Selanjutnya dilakukan uji coba dengan uji lapangan terbatas. Dalam uji coba modul ini, fasilitator yang berperan dalam membimbing siswa adalah guru mata pelajaran matematika mereka sendiri. Hal ini dilakukan dengan pertimbangan agar siswa telah akrab, nyaman, dan tidak membutuhkan waktu untuk beradaptasi dengan fasilitator yang 
baru. Fungsi fasilitator menanggapi hasil pemikiran siswa berupa pertanyaan atau kesulitan yang dialami dalam menyelesaikan masalah yang bersifat mengarahkan, membimbing, memotivasi dan membangkitkan semangat belajar siswa (Salinan Lampiran III Permendikbud No 59 Tahun 2014, 2014: 384). Sebelum pembelajaran dimulai, fasilitator berdiskusi dengan penulis terkait penerapan modul dalam pembelajaran, agar modul dapat digunakan secara tepat sesuai visi misi penyusunan modul. Dalam tahap uji coba modul diperoleh skor kepraktisan dan keefektifan modul yang menjadi bahan perbaikan sebelum dilakukan pengujian modul. Data keterlaksanaan selama lima kali proses pembelajaran terangkum pada Tabel 2.

Tabel 2. Perhitungan Skor Kepraktisan Modul pada Uji Coba Modul

\begin{tabular}{ccccccc}
\hline \multirow{2}{*}{$\begin{array}{c}\text { Pertemuan } \\
\text { ke- }\end{array}$} & Penilai & \multicolumn{2}{c}{ Skor } & $\begin{array}{c}\text { Jumlah } \\
\text { Butir }\end{array}$ & $\begin{array}{c}\text { Jumlah } \\
\text { Skor }\end{array}$ & Rerata \\
\cline { 3 - 4 } & & 0 & 1 & 12 & 12 & 0,8 \\
\hline I & Fasilitator & 3 & 12 & 15 & 11 & 0,73 \\
\hline \multirow{2}{*}{ II } & Pengamat & 4 & 11 & 15 & 15 & 1 \\
& Fasilitator & 1 & 15 & 15 & 15 & 1 \\
\hline III & Pengamat & 0 & 15 & 15 & 15 & 1 \\
& Fasilitator & 0 & 15 & 15 & 15 & 1 \\
\hline IV & Pengamat & 0 & 15 & 15 & 15 & 1 \\
& Fasilitator & 0 & 15 & 15 & 15 & 0,93 \\
\hline V & Pengamat & 1 & 14 & 15 & 14 & 1 \\
& Fasilitator & 0 & 15 & 15 & 15 & 1 \\
\hline
\end{tabular}

Hasil pengamatan selama 5 kali proses pembelajaran menggunakan modul diperoleh skor kepraktisan modul adalah 0,946 dari skala 1, yang artinya modul dikatakan praktis digunakan dalam pembelajaran. Hasil pengisisan kuisioner lembar respon siswa setelah menggunakan modul adalah 3,03 dari skala 4, yang berarti modul berada pada kriteria baik, sehingga modul dapat dikatakan efektif untuk digunakan dalam pembelajaran.

Tahap disseminate (penyebaran) meliputi pendistribusian modul. Pendistribusian modul dilakukan setelah melakukan perbaikan berdasarkan saran dan komentar siswa pengguna pada tahap uji coba. Modul kemudian dicetak dan dijilid untuk siap digunakan pada tahap pengujian modul. Sampul dan isi modul dicetak pada kertas HVS 80 gram, sedangkan sampul modul dilaminating press. Modul dijilid dengan jilid spiral, sehingga hasil akhir diperoleh modul berukuran kuarto atau letter yaitu 216×279 mm. Modul tersebut digunakan sebagai sumber belajar pada materi limit fungsi aljabar, dan menjadi salah satu referensi sumber belajar materi limit fungsi aljabar pada tahun ajaran selanjutnya. 
Pengujian modul dilakukan untuk membandingkan prestasi belajar siswa yang menggunakan modul dengan siswa yang tidak menggunakan modul selama pembelajaran. Selanjutnya diambil sampel yaitu kelas eksperimen dimana siswanya menggunakan modul dalam pembelajaran dengan pendekatan discovery learning, dan kelas kontrol dimana siswanya tidak menggunakan modul. Sebelum dilaksanakan pembelajaran dilakukan uji prasyarat pada dua populasi tersebut. Berdasarkan uji prasyarat diperoleh sampel berasal dari populasi berdistribusi normal, homogen, dan seimbang. Selanjutnya dilaksanakan proses pembelajaran, dan diamati kepraktisan, keefektifan, serta uji hipotesis untuk membandingkan prestasi belajar siswa pada kelas eksperimen dengan kelas kontrol pada materi limit fungsi aljabar. Data keterlaksanaan pembelajaran terangkum pada Tabel 3 .

Tabel 3. Perhitungan Skor Kepraktisan Modul pada Pengujian Modul

\begin{tabular}{clccccc}
\hline $\begin{array}{c}\text { Pertemuan } \\
\text { ke- }\end{array}$ & Penilai & \multicolumn{2}{c}{ Skor } & Jumlah & $\begin{array}{c}\text { Jumlah } \\
\text { Butir }\end{array}$ & Rerata \\
\cline { 3 - 4 } I & Fasilitator & 3 & 12 & 15 & 12 & 0,8 \\
& Pengamat & 3 & 12 & 15 & 12 & 0,8 \\
\hline \multirow{2}{*}{ II } & Fasilitator & 2 & 13 & 15 & 13 & 0,86 \\
& Pengamat & 3 & 12 & 15 & 12 & 0,8 \\
\hline \multirow{2}{*}{ III } & Fasilitator & 1 & 14 & 15 & 14 & 0,93 \\
& Pengamat & 0 & 15 & 15 & 15 & 1 \\
\hline \multirow{2}{*}{ IV } & Fasilitator & 0 & 15 & 15 & 15 & 1 \\
& Pengamat & 0 & 15 & 15 & 15 & 1 \\
\hline \multirow{2}{*}{ V } & Fasilitator & 0 & 15 & 15 & 15 & 1 \\
& Pengamat & 0 & 15 & 15 & 15 & 1 \\
\hline
\end{tabular}

Hasil pengamatan selama 5 kali proses pembelajaran menggunakan modul diperoleh skor kepraktisan modul adalah 0,919 dari skala 1, yang artinya modul dikatakan praktis digunakan dalam pembelajaran. Hasil pengisisan kuisioner lembar respon siswa setelah menggunakan modul adalah 3,39 dari skala 4, yang berarti modul berada pada kriteria baik, sehingga modul dapat dikatakan efektif untuk digunakan dalam pembelajaran.

Setelah dilaksanakan proses pembelajaran dan penilaian melalui ulangan harian pada materi limit fungsi aljabar, kemudian dilakukan uji hipotesis untuk membandingkan prestasi belajar siswa kelas eksperimen dan kelas kontrol. Berdasarkan uji hipotesis diperoleh bahwa prestasi belajar siswa kelas eksperimen tidak lebih baik dari prestasi belajar siswa kelas kontrol. Meskipun demikian diperoleh rerata nilai ulangan harian siswa kelas eksperimen adalah 75,09, sedangkan rerata nilai siswa kelas kontrol adalah 73,5 . 
Berdasarkan uji prasyarat dapat dilihat bahwa sampel yang diambil disimpulkan berasal dari populasi-populasi yang normal, homogen dan seimbang. Berdasarkan data sampel, diperoleh bahwa rerata nilai ulangan harian siswa kelas eksperimen lebih tinggi daripada siswa kelas kontrol. Dengan kata lain, dapat disimpulkan bahwa prestasi belajar siswa kelas eksperimen lebih baik daripada siswa kelas kontrol, tetapi perbedaan ini tidak signifikan menurut uji hipotesis. Cramer dan Howitt (2006) menyatakan,"significant impplies that it is not plausible that the research findings are due to chance". Pernyataan itu dapat diartikan bahwa signifikansi menyiratkan bahwa temuan penelitian tidak diperoleh secara kebetulan. Signifikansi dipengaruhi oleh ukuran sampel (Azwar, 2005). Semakin kecil tingkat signifikansi maka peneliti membutuhkan data yang semakin besar, sebaliknya semakin besar tingkat signifikansi maka peneliti membutuhkan data yang semakin kecil (Angga, 2014). Dengan kata lain, untuk mendapatkan signifikansi yang baik diperlukan ukuran sampel yang besar, sebaliknya jika ukuran sampel kecil maka dimungkinkan munculnya kesalahan semakin ada. Hays (Diekhoff, 1992) menyatakan bahwa significance is a statement about the likelihood of the observed result, nothing else, it doens't guarantee that something important or even meaningful has found. Idealnya hasil penelitian tidak hanya dilihat dari signifikansi tetapi juga harus bermakna, karena hal-hal yang tidak bermakna tidak akan berguna dalam dunia nyata. Jika terjadi hasil penelitian tidak signifikan tetapi bermakna maka temuan penelitian tersebut akan tetap berguna setidaknya untuk menjadi bahan kajian ulang bagi peneliti selanjutnya (Angga, 2014).

Berdasarkan pengamatan selama pembelajaran dan komentar siswa sebagai pengguna modul, hasil yang tidak signifikan terjadi karena beberapa faktor diantaranya: 1) Proses penemuan memakan waktu lama (Westwood, 2008). Dalam pembelajaran, proses adaptasi siswa terhadap modul yang membutuhkan waktu cukup lama terutama terhadap karakteristik discovery learning dalam menemukan materi; 2) Siswa didorong terlibat aktif dan memiliki pengalaman melakukan percobaan (Slavin, 1977); 3) Karakteristik discovery learning tergantung pada siswa yang memiliki keaksaraan memadai, berhitung, kemampuan belajar mandiri dan self-manajemen (Westwood, 2008). Dalam pembelajaran, bagi siswa yang kemampuan kognitifnya rendah, penggunaan modul secara mandiri ini menyulitkan siswa karena siswa lebih menyukai bimbingan intens dari guru; 4) Guru tidak memantau kegiatan secara efektif, tidak mampu memberikan dorongan individu dan bimbingan (scaffolding) yang dibutuhkan siswa (Westwood, 2008). Siswa yang pasif tidak berani mengajukan pertanyaan maupun 
meminta bimbingan secara khusus baik itu dengan teman diskusi maupun fasilitator, sehingga membiarkan diri dalam ketidakpahaman.

Hasil pengembangan modul ini juga dibandingkan dengan modul lain yang telah ada. Modul hasil pengembangan ini bertujuan untuk menjadikan proses pembelajaran lebih bermakna. Karakteristik modul hasil pengembangan yang membedakannya dengan modul lain yang telah ada yaitu: 1) Dari aspek materi, karakteristik modul hasil pengembangan adalah materi yang dikembangkan didasarkan pada analisis silabus di sekolah sehingga telah sesuai dengan kebutuhan sekolah, materi disajikan dalam bentuk penemuan yaitu sehingga tercipta kemandirian dan penghargaan terhadap proses belajar itu sendiri, serta materi disajikan melalui pengamatan contoh-contoh kemudian kesimpulan ditarik secara induktif; 2) Dari aspek skenario pembelajaran, karakteristik modul hasil pengembangan adalah pembelajaran menggunakan modul dimana materi disajikan dengan karakteristik discovery learning, sehingga tercipta suasana penemuan, berpikir kritis, partisipasi dan interaksi tinggi, serta meningkatkan kemampuan menganalisis, mensintesis, dan mengevaluasi (Balm, 2009); 3) Dari aspek kegiatan belajar siswa, karakteristik modul hasil pengembangan diantaranya: a) Stimulation yaitu siswa dirangsang dengan penyajian masalah melalui pernyataan atau gambar, sehingga dapat menimbulkan keinginan siswa untuk menyelidiki masalah; b) Problem statement yaitu siswa diajak mengidentifikasi masalah relevan, sehingga meningkatkan kemampuan siswa mengidentifikasi masalah utama yang fokus untuk dipecahkan; c) Data collection yaitu siswa diajak untuk mengumpulkan data relevan untuk menjawab masalah, sehingga meningkatkan kemampuan dalam memilih mana data yang relevan sebagai pemecahan masalah, dan mana data yang tidak relevan untuk diabaikan atau disimpan sebagai data pendukung; d) Data processing yaitu siswa diajak mengolah informasi yang telah dikumpulkan kemudian menafsirkannya, sehingga dapat meningkatkan kemampuan siswa dalam menganalisis dan mensintesis; e) Verification yaitu siswa diajak melakukan pemeriksaan untuk membuktikan kebenaran jawaban, sehingga menumbuhkan sikap tidak mudah puas dan kemampuan berpikir evaluatif; f) Generalization yaitu siswa diajak menarik kesimpulan dari masalah yang telah dipecahkan, sehingga meningkatkan sikap siswa agar berpikir sistematis dan kemampuan mengaitkan data lapangan yang telah diolah dengan hipotesis yang dibuat.

\section{SIMPULAN DAN SARAN}

Simpulan hasil pengembangan modul pembelajaran dengan pendekatan discovery learning pada materi limit fungsi aljabar dinyatakan: 1) valid dengan skor kevalidan 3,4 
yang berada pada kriteria baik; 2) praktis digunakan dalam pembelajaran dengan skor kepraktisan 0,919 yang berada pada kriteria sangat baik; 3) efektif untuk digunakan dalam pembelajaran dengan skor keefektifan 3,03 yang berada pada kriteria baik; dan 4) prestasi belajar siswa yang menggunakan modul pembelajaran dengan pendekatan discovery learning lebih baik dari siswa yang tidak menggunakan modul pembelajaran dengan pendekatan discovery learning, tetapi tidak signifikan.

Saran yang dapat dikemukakan sebagai berikut: 1) Bagi guru yaitu menjadikan modul pembelajaran dengan pendekatan discovery learning sebagai sumber belajar yang digunakan pada tahun selanjutnya khususnya pada materi limit fungsi aljabar. Dengan pendekatan discovery learning, siswa akan terkondisikan untuk aktif selama pembelajaran, menemukan ide untuk menyelesaikan masalah, meningkatkan partisipasi serta interaksi antar siswa. Adanya komentar bahwa siswa tidak terbiasa belajar secara mandiri menunjukkan modul ini penting dipertimbangkan untuk mengurangi porsi guru dalam menjelaskan detail suatu materi; 2) Bagi siswa yaitu dapat mengondisikan diri untuk menemukan makna bagaimana suatu pengetahuan dibentuk, meningkatkan kemampuan menganalisis, mensintesis, serta mengevaluasi. Melalui modul, siswa hendaknya berusaha belajar secara mandiri, aktif, tidak bergantung detail pada penjelasan guru; 3) Bagi peneliti lain yaitu digunakan sebagai referensi untuk melakukan penelitian pengembangan lain guna menciptakan kemandirian belajar, meningkatkan keaktifan, partisipasi dan interaksi antar siswa, serta kemampuan pemecahan masalah siswa.

\section{DAFTAR PUSTAKA}

Angga, F. (2014, 11 Maret). Menangani Hasil Pengujian Hipotesis yang Tidak Signifikan (Bagian Pertama: Pengertian Signifikan). FNI Statistics. Diperoleh 23 Juli 2016, dari http://fni-statistics.blogspot.co.id/2014/03/PengertianSignifikan.html?m=1.

. (2014, 13 Maret). Menangani Hasil Pengujian Hipotesis yang Tidak Signifikan (Bagian Kedua: Signifikansi + Bermakna dan Mengatasi Riset Tidak Signifikan). FNI Statistics. Diperoleh 23 Juli 2016, dari http://fnistatistics.blogspot.co.is/2014/03/menangani-hasil-pengujian-hipotesis.html?m=1.

Azwar, S. (2005). Signifikan atau Sangat Signifikan?. Buletin Psikologi UGM Vol.13, No.1, Hal.38-44.

Balitbang Kemdikbud. (2014). Panduan Pemanfaatan Hasil Ujian Nasional Tahun Pelajaran 2013/2014. Jakarta: Puspendik Balitbang Kemdikbud.

. (2015). Panduan Pemanfaatan Hasil Ujian Nasional Tahun Pelajaran 2014/2015. Jakarta: Puspendik Balitbang Kemdikbud. 
Balm, A. G. (2009). The Effects of Discovery Learning on Students Success and Inquiry Learning Skills. Egitim Arastirmalari-Eurasian Journal of Educational Research, 35, 1-20.

Budianingsih, A.C. (2005). Belajar dan Pembelajaran. Jakarta: Rinekacipta.

Chambers, D., Chambers, L., \& Thiekotter, A. (2013). Preparing Students Nurses for Contemporary Practise: The Case for Discovery Learning. Journal of Nursing Education and Practise. 3(9). ISSN 1925-4059. Online. www.sciedu.ca/journal/index.php/jnep/issue/archive. Diperoleh 27 Januari 2016

Chramer, D. \& Howitt, D. (2006). The Sage Dictionary of Statistics. London: Sage Publication

Cruickshank, D.R, Jenkins, D.B, \& Metcalf, K.K. (2009). The Act of Teaching, Fifth Edition. Boston: McGraw Hill Companies.

Daryanto. (2013). Menyusun Modul Bahan Ajar Untuk Persiapan Guru Dalam Mengajar. Yogyakarta: Gava Media.

Depdiknas. (2008). Kamus Besar Bahasa Indonesia Pusat Bahasa. Jakarta: Gramedia Pustaka Utama.

Diekhoff, G. (1992). Statistics for the Social and Behavioral Sciences: Univariate, Bivariate, Multivariate. Dubuque: Wm.C.Brown Publishers.

Huda, M. (2014). Model-Model Pengajaran dan Pembelajaran (Isu-Isu Metodis dan Paradigmatis). Yogyakarta: Pustaka Pelajar.

Nichols, J.R. (2013). 4 Essential Rules of 21st Century Learning. Teachthought. http://www.teachthought.com/learning/4-essential-rules-of-21st-centurylearning/. Diperoleh 30 September 2015.

Orton, A. (1987). Learning Mathematics. London: Casel 1 Educational Limited.

Purwanto. (2007). Pengembangan Modul. Jakarta: Pusat Teknologi Departemen Pendidikan Nasional.

Salinan Lampiran III Peraturan Menteri Pendidikan dan Kebudayaan Nomor 59 Tahun 2014 Tentang Kurikulum 2013 Sekolah Menengah Atas/Madrasah Aliyah.

Slavin, R. E. (1977). Cooperative Learning and Student Diversity. In R. Ben-Ari dan Y. Rich (Eds.), Enhancing Education in Heterogeneous Schools (pp. 215-247). Israel: Bar-Ilan University Press.

Syah, M. (2004). Psikologi Pendidikan dengan Pendekatan Baru. Bandung: Remaja Rosdakarya.

Westwood, P. (2008). What Teachers Need To Know About Teaching Method. Victoria: ACER 